\title{
A Problemática Universitária
}

$\mathrm{S}$

ão muitas as instituições que ainda não alcançaram, em nosso pais, a plenitude de suas possibilidades teóricamente realizáveis. A imaturidade de nossa cultura parece ser a causa, de ordinário, apontada como o principal fator do quase malogro de algumas delas.

Nossos problemas acumulam-se a cada passo, desafiando a inteligência e o bom senso dos que se julgam ou se sentem autorizados a sugerir soluções e a combater a inércia dominante. É o sistema politico, que ainda não se encontrou a si mesmo, longe que está da verdadeira prática da democracia. É a ordem econômica, que mal consegue garantir a modesta subsistência de uma multidão cada dia maior de brasileiros. São, enfim, os grandes desniveis sociais a entravar o harmonioso desenvolvimento do pais.

O fato é que essa atmosfera assim carregada de defeitos e vicios perturba tôda a ampla perspectiva de criação e progresso com que nos habituamos a, vaidosamente, olhar a realidade brasileira. Esta como que se amesquinha diante dos erros e das improvisações reinantes no meio social.

As instituições universitárias teriam, em conseqüência, de refletir, desta forma, as mesmas imperfeições que dificultam a existência ou o funcionamento, entre nós, das demais instituições. Particularmente, elas, tão sensiveis ao menor desvirtuamento ou deturpação de suas finalidades transcendentais, não poderiam deixar de ressentir o efeito do ambiente sócio-cultural.

Dai porque sejam de todo justas as preocupaçóes com que alguns dos nossos melhores pensadores costumam, hoje, encarar - problema da educação no âmbito universitário. Preocupação, antes de mais nada, pela missão reservada à Universidade nos quadros do mundo contemporâneo.

Criação histórica da Idade Média, a Universidade viu, com o passar dos séculos, transformarem-se, não sòmente os diversos 
sistemas de vigências predominantes em cada um dêles, como também a sua destinação e os seus objetivos. Com esta variação do fim, teria de mudar, como efetivamente mudou, o espirito que a tem animado: ela traduz, sem dúvida, a filosofia de vida e de educação em vigor durante certo periodo.

Eis porque já se cuida, como o faz Tristão de Ataide, de uma tipologia universitária, que proceda, ainda que didàticamente, a uma classificação das Universidades, segundo critérios ou fatos que as aproximem ou afastem.

A Universidade eclética, para usar a terminologia que é a dêle, representa aquela em que as ciências naturais tendem a predominar em detrimento das ciências culturais. Modêlo das Universidades do século XIX, e mesmo do século $X X$, ela é "dominada, consciente ou inconscientemente, pelo cientificismo que the forneceu a nota mais caracteristica". Na Universidade ditigida, ao contrário, a posição das ciências sociais obedece a uma politica ditada no interêsse de um Estado ou de um Partido. É, pois, tipica dos regimes totalitários de qualquer natureza.

Finalmente, a Universidade orgânica, em oposição às anteriores, realiza "uma primazia hierárquica das ciências culturais, isto é, das que formam a personalidade humana em sua integridade, sem prejuizo da autonomia e da importância intrinseca das ciências naturais e das ciências sociais". A opção entre êsses modelos dependerá, evidentemente, da interferência de vários fatôres, entre os quais o nivel moral, politico e econômico do pais.

No caso do Brasil, se as deficiências e omissões existentes são comprometedoras, não há porque não reconhecer que temos condições de superá-las. É animador, com efeito, constatar o trabalho de pesquisa, de equacionamento, de elucidação já feito em tôrno dos nossos problemas fundamentais, em todos os setores de atividade. Os resultados mesmo parciais comprovam o alto grau de recuperação e adaptação do homem brasileiro. Tanto mais lisonjeiros, êsses resultados, quanto formam apenas o contingente de esfôrço civilizador de uma pequena minoria da população.

O importante para nossas instituiçóes, e, de modo especial, para as de natureza educacional, está em não improvisarmos soluçóes imediatistas, a curto prazo. A pressa poderá agravar os defeitos, ao invés de corrigi-los ou atenuá-los. Nesse sentido, é melhor não fazer, do que fazer sem pensar, ou fazer mal. 
No aperfeiçoamento das instituições, e em seu benefício, encontrarão assim nossas Universidades uma das razões de sua própria existência. Conhecemos todos o papel que alguns centros de cultura no exterior têm desempenhado em favor do desenvolvimento dos seus respectivos paises, - pelo pensamento criador, pela investigação consciente, pelas lições ministradas.

Reformar-se não significará, necessàriamente, para nossas Universidades, dar apenas nova estrutura aos cursos, estabelecer uma hierarquia entre as disciplinas ou acumular conhecimentos sem nenhum valor objetivo. Terão de integrar-se, pois, na vida da nação e do povo, construindo, não sòmente nosso patrimônio moral e intelectual, senão, também participando, ativamente, da luta para a formação da riqueza material do pais.

A essa luta não tem faltado o concurso da inteligência e do entusiasmo dos mestres e discipulos da Universidade do Rio Grande do Sul. Das mais jovens que possuimos, a Universidade gaúcha tem visto crescer tanto o seu magnifico conjunto arquitetônico, como sobretudo, o seu prestigio e o campo de trabalho. Trabalho organizado e dinâmico empreendido em cursos normais ou de extensão universitária, na faina silenciosa dos institutos especializados e no contato de professôtes e alunos com situações e realidades extra-universitárias.

$A$ atenção que a Universidade vem dispensando, sem exageros ou prioridades, aos diversos ramos do saber humano, imprime aos seus programas um caráter de universalidade, que a recomenda diante das congêneres. Por outro lado, tornou-se, na medida do possivel, uma Universidade aberta ao diálogo, o que explica o sucesso de muitas reuniões nacionais e internacionais, ali promovidas. É um traço que marca, simpàticamente, a Universidade do Rio Grande do Sul, êsse de saber receber bem para o debate sério e proveitoso.

Voltada para essas relações de intercâmbio com as suas co-irmãs, brasileiras ou não, a Universidade não descuida, por êsse motivo, de incentivar o estudo e o culto de tantas tradiçóes, que a geografia, a economia e a personalidade do povo gaúcho criaram.

Estamos certos de que, sob a direção de homens do discernimento e da sabedoria do Reitor Elyseu Paglioli, essas virtudes irão acentuando-se com o tempo e que a Universidade do Rio Grande do Sul será das primeiras, por conseguinte, a cumprir integralmente os objetivos de uma autêntica Universidade do século $X X$. 